Volume 14

October 2015

\title{
The Recent Transformation of Medical Liability in Jewish Law
}

Steven F. Friedell

Follow this and additional works at: https://via.library.depaul.edu/jhcl

\section{Recommended Citation}

Steven F. Friedell, The Recent Transformation of Medical Liability in Jewish Law, 14 DePaul J. Health Care L. 441 (2013)

Available at: https://via.library.depaul.edu/jhcl/vol14/iss3/3

This Article is brought to you for free and open access by the College of Law at Digital Commons@DePaul. It has been accepted for inclusion in DePaul Journal of Health Care Law by an authorized editor of Digital Commons@DePaul. For more information, please contact digitalservices@depaul.edu. 


\title{
THE RECENT TRANSFORMATION OF MEDICAL LIABILITY IN JEWISH LAW
}

\author{
By Steven F. Friedell
}

The doctors of an earlier period had good reason to fear the practice of their craft. In the two millennia preceding 1800 , most medical remedies were either useless or harmful, ${ }^{1}$ a condition that has improved in modern times. ${ }^{2}$ Prior to 1800 , doctors for the most part did not advocate specific drugs for the direct treatment of specific illnesses. Although there were many schools of thought as to the nature and treatment of disease, ${ }^{3}$ doctors and patients shared the belief that to confront most diseases one needed to help the body regain its natural equilibrium through diet, ventilation, bloodletting, emetics, diuretics, purgatives, and medicines to promote perspiration. ${ }^{4}$ A common belief, reflected in Jewish sources ${ }^{5}$ and having its

\footnotetext{
- Professor of Law, Rutgers School of Law - Camden. My thanks to Perry Dane, Chaim Saiman, and Yuval Sinai and to the participants at the Jewish Law Association conference at Yale in August 2012 and to my Rutgers colleagues who participated in a faculty workshop for their thoughtful comments on an earlier draft. I am also grateful to Dr. Andrea Baldeck and Robert Hicks for their insights into the history of medicine.

1. Charles E. Rosenberg, The Therapeutic Revolution: Medicine, Meaning, and Social Change in Nineteenth-Century America, in THE THERAPEUTIC REVOlUTION: ESSAYS IN THE SOCIAL HISTORY OF AMERICAN MEDICINE 3-8 (Morris J. Vogel \& Charles E. Rosenberg eds. 1979); Maimonides thought that many acts of malpractice did not result in harm but that the majority of people die as a consequence of medical treatment, "because of the ignorance of most physicians about Nature." Moses Maimonides' Two Treatises on the Regimen of Health, 54:4 n.s. TRANSACTIONS OF THE AM. PHIL. SOC'Y 21 (1964).

2. Serious problems have persisted. See OtIS Webb Brawley with Paul Goldberg, How We Do HARM (2011) (examples of harm by overtreatment, experimental treatment, and inadequate treatment); SIDDHARTHA MUKHERJEe, EMPEROR OF ALl MALADIES: A BIOGRAPHY OF CANCER 197 (2010) (radical mastectomies that were the most common treatment for breast cancer for most of the twentieth century were either useless or unnecessary); Elisabeth Rosenthal, Let's (Not) Get Physicals, N.Y. Times, June 3, 2012, Sunday Review at 1 , available at http://www.nytimes.com/

2012/06/03/sunday-review/lets-not-get-physicals.html ("annual physical exams - and many of the screening tests that routinely accompany them - are in many ways pointless or (worse) dangerous, because they can lead to unnecessary procedures"); Joe Klein, The Long Goodbye, 179 TIME, no. 23 June 11, 2012, at 23-24, available at http:/www.time.com/time/magazine/article/

$0,9171,2116137,00 . \mathrm{html}$ (President of Geisinger Health System estimates that " $40 \%$ of what doctors and hospitals do is wasteful"); Dan Negoianu \& Stanley Goldfarb, Just Add Water, 19 J. AM. Soc. NEPHROLOGY 1041 (2008) (debunking the myth that under normal circumstances a healthy person should drink eight to ten glasses of water per day to remove toxins, improve kidney function or for cosmetic reasons).

3. See generally C.G. Cumston, An InTRoduction to the History of Medicine (1926).

4. Rosenberg, supra note 1 , at 6 . "The effectiveness of the system hinged to a significant extent on the fact that all of the weapons in the physician's normal armamentarium worked: 'worked,' that is, by providing visible and predictable physiological effects..." Id. at 8 .

5. See also Otzar Hamidrashim (J.D. Eisenstein) Midrash Temurah ch. 1. See also Rabbi Menahem ben Aaron ibn Zerah (c.1310-1385), Tzeidah La-derekh 1:1:7 (living things are made of four elements, namely
} 
roots in early Greek medicine, was that the body's four humors needed to be kept in balance. ${ }^{6}$ Both Jews and non-Jews believed that it was God's will when medicine failed to cure a patient. ${ }^{7}$

In 1860 Dr. Oliver Wendell Holmes said of the medicine of his day:

Throw out opium, which the Creator himself seems to prescribe, for we often see the scarlet poppy growing in the cornfields, as if it were foreseen that wherever there is hunger to be fed there must also be a pain to be soothed; throw out a few specifics which our art did not discover, and it is hardly needed to apply; throw out wine, which is a food, and the vapors which produce the miracle of anaesthesia, and I firmly believe that if the whole materia medica, as now used, could be sunk to the bottom of the sea, it would be all the better for mankind,- - and all the worse for the fishes.

But to justify this proposition, I must add that the injuries inflicted by over-medication are to a great extent masked by disease. $^{8}$

Although doctors could treat common wounds and set fractures, the placebo effect played a large role in many patients' recovery. ${ }^{9}$ The state of medieval surgery was far worse. It was not a branch of medicine and was practiced by people with little training, often as a desperate last resort. ${ }^{10}$

From the Talmudic era through the Middle Ages, astrology played a role in medical treatment. ${ }^{11}$ Perhaps the best that can be said about it is that by restricting treatments to certain times or days, it prevented some

earth, water, air, and fire); $i d$. at 1:1:9 (the four humors correspond to the four elements); id. at 1:3:3-11 (a description of six factors contributing to health or disease corresponding to Galen's six non-naturals plus washing and rinsing which he considers to be a non-compulsory factor).

6. CumSTON, supra note 3, at 159-63.

7. Compare Rosenberg, supra note 1, at 10-11 (quoting a nineteenth-century doctor) with Rabbi Jehiel Michal Epstein, Arukh Ha-Shulhan Yoreh De'ah (late nineteenth- early twentieth-century) 336:2; Rabbi Joshua Falk (1555-1614), Perisha Tur, Yoreh De'ah 336 n.7; Responsa Besamim Rosh 386. In early nineteenth-century America, beliefs in divine providence played a role in discouraging patients from suing for malpractice and led juries to exonerate doctors. K.A. DE VilLE, MEDiCAL MALPRACTICE IN NINETEENTHCENTURY AMERICA 121-29 (1990).

8. Oliver Wendell Holmes, Currents and Counter-Currents in Medical Science, in OLIVER WENDELL HOLMES, MEDICAL ESSAYS 1842-1882, 202-03 (1891) (footnote omitted). Dr. Holmes regretted that his words had been misquoted or taken out of context. Preface to the New Edition, id. at xv.

9. See Rosenberg, supra note 1 , at 9 ("on the emotional level, the very severity of drug action assured the patient and his family that something was indeed being done.")

10. See Michael R. MCVaugh, Medicine Before the Plague: Practitioners and their Patients IN THE CROWN OF ARAGON, 1285-1345, at 183 (1993).

11. E.g., Shab. 129 b. 
harmful treatments. Beginning with Ibn Ezra, ${ }^{12}$ some rabbis limited the scope of medical care to the treatment of external injuries. ${ }^{13}$ Although this teaching, which was consistent with the Methodist school of Greek medicine,${ }^{14}$ was a minority position within Jewish law, it also probably prevented much harm.

Recognizing that doctors might feel reluctant to practice their skill, many of the classical sources of Jewish law from Nahmanides (who lived from 1194-1270) through the later codes adopt a carrot-and-stick approach based apparently on an earlier takanah that is reflected in the Tosefta. ${ }^{15}$ The Shulhan Arukh sums up the rules as follows:

The Torah gave the doctor permission to heal, and it is a commandment that is included in the obligation to save life. If he prevents himself [from healing] then he sheds blood. . . . However, a person should not practice medicine unless he is an expert and unless there is none present who is greater than him, for otherwise he sheds blood. If he treated without the permission of the court, he is liable to make compensation even if he is an expert. If he treated with permission of the court and erred and caused injury, he is exempt under the laws of man but liable under the laws of Heaven, and if he killed [the patient] and it is known to him that he was inadvertent, he goes into exile on his account. ${ }^{16}$

Nahmanides and the later codes teach that it is a mitzvah to heal another but one who withholds treatment is guilty of bloodshed. These authorities allow payment for the doctor's trouble and loss of time but prohibit payment for his skill and learning. They expose the unlicensed physician to liability for compensation in a court of man but limit the licensed expert physician's liability for errors to the laws of heaven. Because the concept of "error" suggests a departure from the professional norm, it probably includes most types of medical malpractice.

A licensed physician whose patient dies as a result of inadvertence is

12. Commentary of Abraham ibn Ezra to the Torah, Exodus 21:19 (longer version) (Abraham ibn Ezra lived from 1089-1164).

13. This view was followed by many others including Rabbi Jonathan Eybeschuetz (1695-1764), Hiddushei Hilkhot Niddah 188:5; Rabbi Jacob Emden, (1697-1776), Mor U-ketziah 328; Rabbi Elijah ben Solomon Zalman, the Vilna Gaon (1720-1797), Aderet Eliyahu Ex. 21:19 (commentary).

14. See Ron Barkai, A History of JeWish GynaeCologiCal TEXTS IN THE Middle Ages 40 (1998); I.E. Drabkin, Soranus and his System of Medicine, 25 BULL. OF HIST. OF MED. 503, 510-12 (1951) (for most acute diseases drugs were to be used only extemally; surgery could be employed only when diet and drugs have no effect; Soranus preferred gentle treatments to the harsh treatments of the Dogmatists).

15. Tosefta Gitt. 3:8 (Tosefta was probably compiled by the end of the second century A.D.).

16. Shulhan Arukh, Yoreh De ah 336:1 (1565). 
theoretically subject to exile, but the meaning of this is difficult because exile for manslaughter was not applicable after the Temple's destruction. It seems most likely to be taken as a warning to doctors of the seriousness of the matter and perhaps to impress on doctors a sense that they ought to voluntarily contribute to the survivor's welfare to atone for their act. ${ }^{17}$ It may also have reflected the common occurrence of doctors leaving town following a fatality. ${ }^{18}$ However, consistent with Jewish law regarding wrongful death, no monetary damages are owed as a matter of formal law. ${ }^{19}$

According to Nahmanides, the erring expert doctor who had permission of the court has a heavenly obligation to pay only for depreciation (nezek). ${ }^{20}$ As explained by the Shakh, there is liability in the courts of man if the doctor intentionally injured the patient. ${ }^{21}$ For the most part these sources describe the law as set forth in the Tosefta. ${ }^{22}$ However, in one place the Tosefta says, "If an expert physician having permission of the court to heal injured, he is exempt, but if he did more harm that was appropriate he would be liable." 23 Although some sought to harmonize the various statements of the Tosefta, ${ }^{24}$ they may indeed reflect different views. ${ }^{25}$ In any event, neither Nahmanides, the Tur nor the Shulhan Arukh codify the rule of liability for doing more harm than is appropriate.

In Anglo-American law of medical malpractice, various cultural factors influenced patients' attitudes about asserting malpractice claims and juries' assessments of those claims, but the doctrine governing malpractice has remained relatively stable, imposing liability for doctors who fail to meet the ordinary care expected of members of their profession. ${ }^{26}$ The dif-

17. Rabbi Isaac Jacob Weiss, Responsa Minhat Yitzhak 3:104.

18. See Steven F. Friedell, Medical Malpractice in Jewish Law: Some Parallels to External Norms and Practices, 6 CHI-KENT J. INT'L \& COMP. L. 1, 19 (2006).

19. For a full discussion of wrongful death in Jewish law, see Judge Drori's opinion in CC (Jer) 5380/03, Estate of R.v. Tz., [2009] IsrDC Tak-Mah 2009(1) 8,208 at \$9 243, 249-273.

20. Nahmanides, Torat Ha-adam in 2 H.D. Chavel, Kitvei Rabbeinu Moshe ben Nahman 41-42 (1963/64). Depreciation is measured by assuming that the injured victim was a slave sold in the market place. A defendant is liable for pain, medical expense, and loss of time only if he acts with intent or inadvertence close to intention. A defendant is liable for humiliation only if he acts with intent. See Shalom Albeck \& Menachem Elon, Damages in 5 ENCYCLOPAEDIA JUDAICA 385, 386 (2d ed. 2007).

21. Shakh, Shulhan Arukh, Yoreh De'ah 336 n.2.

22. Tosefta Gitt. 3:8 (S. Lieberman ed.); BK 6:17 (S. Lieberman ed.); Makk. 2:5 (M. Zuckermandel ed.).

23. Tosefta BK 9:11 (S. Lieberman ed.).

24. The Tashbetz made this effort. He thought that if a surgeon did more than what was appropriate he would be considered to have acted intentionally. See infra text at n.49. According to Rabbi Hayyim David Halevi, doing what is appropriate apparently means making the correct diagnosis and designing the proper treatment. See infra text at n.68.

25. Rabbi Meir Simcha Hakohen of Dvinsk (1843-1926), Or Sameah Hil. Rozeah 5:6.

26. See K.A. De Ville, supra note 7, at 6 (standard of care); id. at 114-18 (variety of factors, including intra-professional rivalry, expectations of medical treatment, religious beliefs, and community sanctions, 
ferences between the Anglo-American law of medical malpractice and the law according to Nahmanides, the Tur, and the Shulhan Arukh are apparent. These rabbinic sources expose an expert licensed doctor to liability for errors only in a heavenly court. These sources do not impose a reasonableness standard, nor do they expose doctors to liability even in a heavenly court for pain or medical expense if caused unintentionally. Further, they do not impose liability for omissions or for failure to obtain informed consent.

In recent years, however, rabbis, scholars and Israeli judges have reformulated Jewish law in each of these respects. Some have imposed a duty of reasonable care and exposed doctors to a full range of damages including pain and suffering and medical expenses. Some have exposed doctors to liability for omissions and for failure to obtain informed consent. This transformation appears to be an instance where Western legal norms have played an indirect role in influencing the development of Jewish law. Western law has created a heightened duty of care for doctors and provided society with a remedy against doctors in the form of damages should treatment fall below such standard. Indeed one of the responsa in this area was addressed to a questioner who expressly wanted to know if Jewish law would afford a patient with the same protection as Israeli tort law. ${ }^{27}$ Contemporary rabbis, scholars and Israeli judges have strived to present Jewish law in a way that meets the public's expectations.

The radical change in the law creates difficulties for the haredi communities and those engaged in the Mishpat Ivri movement. For the former, the so-called ultra-Orthdodox communities, Jewish law provides the governing norms. Members of these communities feel obligated to resolve their disputes in rabbinic tribunals ${ }^{28}$ and believe that Jewish law is un-

influencing suits against doctors). Cf. 3 WILlIAM BLACKSTONE, COMMENTARIES ON THE LAW OF ENGLAND 122 (1768) (one has a right to redress for "neglect or unskillful management of his physician, surgeon, or apothecary"). Essentially the same standard applied in fourteenth-century England where doctors were engaged in a common calling and could be sued under the writ of assumpsit even in the absence of a promise to avoid harm. Theodore Silver, One Hundred Years of Harmful Error: The Historical Jurisprudence of Medical Malpractice, 1992 WIS. L. REV. 1193, 1195-1205 (1992). In Medieval Europe, a doctor's malpractice could be grounds for denying the collection of a fee. See MiCHAEL R. MCVAUGH, MEDICINE BEFORE THE PLAGUE 182 (1993). Some doctors faced prosecution and sought to protect themselves by contract before treating difficult cases. J. Shatzmiller, Doctors' Fees and Their Medical Responsibility, in P. Brezzi, E. Lee (eds.) SourCes of SocIAL History: Private ACTS OF THE LATE MIDDLE AGEs 201, 206-08 (1984).

One of the most notable developments in American law has been treating lack of informed consent as a type of negligence rather than a claim for battery. See W. PAGE KEETON, PROSSER AND KEETON ON THE LAW OF TORTS 189-90 (5th ed. 1984). Many states have recognized a patient standard for informed consent. E.g., Canterbury v. Spence, 464 F.2d 772 (D.C. Cir. 1972). Another feature of American law has been the rise and decline of the locality rule. See Silver, supra note 26, at 1226-36.

27. Rabbi Hayyim David Halevi, Aseh Lekha Rav, Responsum No. 30, vol. 3 (1978/79), 138.

28. The prohibition against litigating in non-rabbinic tribunals even if these tribunals apply Jewish law is 
changeable. ${ }^{29}$ Yet haredi rabbis have been able to reinterpret the Jewish law codes governing medical malpractice to meet the needs of the time even though these codes are clear on their face. When these rabbis do so, one might question whether they are really using Jewish law or are merely enforcing a different set of norms.

A similar problem confronts those within the Mishpat Ivri movement who recognize that the State of Israel has the legitimate power to create the governing law but seek to have Jewish law influence the development of Israeli law. The movement has achieved some success as many court decisions have cited Jewish law at least as dicta. ${ }^{30}$ Israeli courts frequently employ comparative law, but their use of Jewish law serves a different function. Normally a court will look to foreign law to establish that a rule is functional, that its adoption will achieve uniformity, and to reinforce the perception that the court is deciding based on reason rather than imposing its own policy choice. ${ }^{31}$ As is the case more generally, Jewish law provides none of these advantages in the medical liability area. It is not functional today and it provides no uniformity. Moreover, when the courts transform Jewish law before "applying" it, they appear to be legislating. The Mishpat Ivri movement seeks to connect the Jewish state to the rich history of the Jewish people. ${ }^{32}$ That goal cannot be achieved with regard to medical liability by applying the codified rules of Jewish law.

Given these challenges for the haredi communities and Mishpat Ivri movement, it is critical that these authorities justify their use of Jewish law governing medical liability. This article critically looks at the reasoning that these authorities have employed and shows that they have not supplied a satisfactory rationale. After considering alternative ways of reforming Jewish law in this area this article will suggest a better way - that authorities recognize that modern medical practice differs so much from that of earlier centuries that one should not regard most of the codified rules on medical liability as being pertinent today. Unlike earlier medical practice, modern medicine is primarily based on science, not on a priori assumptions. Classical Jewish law balanced the conflicting goals of protecting pa-

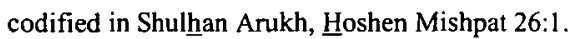

29. Rabbi Moses Sofer (1762-1839), a leading rabbi of his time, famously declared, "The Torah forbids anything new." See Moshe Shraga Samet, Sofer, Moses, 18 ENCYClOPAEDIA JUDAICA 742 (2nd ed. 2007).

30. See Yuval Sinai, Application of Jewish Law IN THE ISRaEli CoURTS (2009) (Heb.).

31. See Steven F. Friedell, Some Observations about Jewish Law in Israel's Supreme Court, 8 WASH. UNIV. GLOBAL STUD. L. REV. 659, 663-64 (2009).

32. See Aharon Barak, Shofet B'Hevra Demokratit 289-90 (2004) (reference to Jewish law is not reference to comparative law but to Israeli law); Aharon Barak, The Values of the State of Israel as a Jewish and Democratic State, 21 JEwISH L. ASS'N STUD. 10 (2011) (in a Jewish state "the values of the Halakhah (religious law) are among its most basic values"). 
tients and encouraging doctors to practice medicine by giving doctors a large measure of immunity. Contemporary doctors have less reason to fear how treatment will affect patients than did doctors of earlier centuries. Also, liability insurance provides a buffer between harm caused and financial ruin. Consequently, society can provide more patient protection without fear that good doctors will quit the profession.

In other ways, however, Jewish law can be useful. Jewish law recognizes the need to exempt doctors from liability for unforeseen consequences or for harm that is an inherent part of good medical practice. That need has not changed. Moreover, if rabbis and judges are willing to apply other aspects of Jewish law by analogy, Jewish law has the necessary tools to support a modern regime governing medical malpractice.

Central to this article's argument will be the idea that any system of law is more than the written sources. Even when the rules of law are clearly stated, one must be careful to examine the underlying context in which those rules were made. When those circumstances have radically changed it is appropriate and necessary to adjust the rules if one is to be true to the larger system of law.

\section{STANDARD OF CARE AND MEASURE OF DAMAGES}

The classic rabbinic sources concerning liability for medical treatment do not speak in terms of reasonable care. They speak of "error" 33 or acting "inadvertently" 34 or "doing more than necessary." ${ }^{35}$ Nahmanides says that a doctor must take the care required in matters of life and death (b'dinei nefashot) and avoid causing injury through transgression (peshi'a), ${ }^{36}$ but this is not defined in terms either of reasonableness or in terms of a standard set forth by the medical establishment. Moreover, Nahmanides does not appear to recognize peshi'a as a separate ground of liability. The first mention in this context of hitrashlut, meaning either neglect or negligence, is in the late 19th-, early 20 th-century work Arukh HaShulhan. There, too, liability for a doctor's neglect or failure to pay proper

33. E.g., Shulhan Arukh, Yoreh De'ah 336:1.

34. E.g., Tosefta Gitt: $3: 8$.

35. E.g., Tosefta BK 9:11.

36. Torat Ha-adam in H.D. Chavel, Kitvei Rabbeinu Moshe ben Nahman, supra note 20, at 42. Similarly, Rabbi Menahem Ibn Zerah (c.1310-1385) Zeidah la-Derekh 5:2:2 wrote that a doctor must not refrain from practicing medicine from fear that he might kill a patient, but must use the best of knowledge and avoid peshi 'a. As for liability, however, a non-expert doctor who has permission of the court is exempt under the laws of man but liable under the laws of Heaven. Id. An expert doctor lacking the court's permission would be liable. Id. Rabbi Menahem does not address the potential liability of an expert having court permission. 
attention is limited to the heavenly tribunal. ${ }^{37}$

A 19th-century Italian scholar, Rabbi Menahem Azariah Meir Castelnuovo, wrote that a doctor would also be liable in the courts of man if he acted with inadvertence close to intention (b'shogeg karov le-mezid), which he notes is the equivalent of peshi' $a{ }^{38}$ Although many today equate peshi' $a$ with negligence, ${ }^{39}$ it is important not to do so. Jewish law recognizes several states of mind, among them being o'ness, shogeg and shogeg karov le'mezid. In Jewish law, the range of compensatory damages and other penalties varies with the state of mind. In distinguishing these states, the Talmud gives the example of man who does not know that a stone has fallen into his lap. ${ }^{40}$ When he stands up the stone injures another. We might think that the man was negligent for not knowing about the stone, but Jewish law considers this to be a case of $o$ 'ness for which the man is liable only for depreciation (nezek). Had the man known that the stone fell onto his lap but later forgot about it, we would again be justified in saying that he was "negligent". ${ }^{41}$ However, the Talmud and its commentators classify this only as shogeg. ${ }^{42}$ In this instance the actor is subject to exile if the stone kills another but again he pays only for nezek in case of injury. ${ }^{43}$ What is shogeg karov l'mezid or peshi'a? Rashi says this describes a man who falls from a roof in a normal wind. ${ }^{44}$ Here is a situation where the defendant either knew the risk of injury or where the risk was obvious, and the defendant pays not only for nezek but also for pain, medical expense and loss of time. Peshi'a thus connotes a greater degree of fault than negligence and is similar in meaning to the Third Restatement's definition of recklessness. ${ }^{45}$

37. Arukh Ha- Shulhan $336: 2$.

38. Rabbi Menahem Azariah Meir Castelnuovo, Misgeret Ha-Shulhan, Yoreh Deah $\S 336: 1$ (1840). (Im pash 'a be'aizeh davar d'poshe 'a karov le'meizid hu). See J. David Bleich, Medical Malpractice and Jewish Law, TRADITION 39:1 (2005), 109-10 n.51.

39. See Bleich, supra note 38 (discussing the opinion of Rabbi Menahem Azariah Meir Castelnuovo). See generally Shalom Albeck \& Yehiel Kaplan, Torts, 20 ENCYCLOPAEDIA JUDAICA 63 (2d ed. 2007).

40. B. Bava Kamma 26b. The likely setting is a man who lets a pebble fall into his lap while sifting grain. See $\mathrm{m}$. Betz 1:8 (one who selects beans into his lap); $\mathrm{b}$. Betz. 13b (a person winnowing grain who lays some on his lap); b. Sot. 14b (pebble found in a meal offering); b. B.B. 93b-94a (when wheat is sold it is expected to have a certain amount of pebbles). The Meiri explains this as a case where another man put it there while he was asleep. Beit Ha-behira, Bava Kamma 26b.

41. Cf. Wilson v. Allstate Ins. Co., 278 So. $2 \mathrm{~d} 814$ (La. App. 1973) (contributory negligence).

42. Bava Kamma. 26b, supra note 40 , and Rashi s.v. L'inyan arba'a devarim patur. See also Shulhan

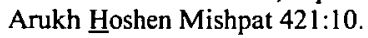

43. See Meiri, Beit Ha-behira, Bava Kamma 26b, supra note 40.

44. Rashi, B.K. 27a s.v. Ve'nitka b 'isha hayyav b'arba'a devarim. See also Tur, Hoshen Mishpat 421.

45. RESTATEMENT (THIRD) OF TORTS: Phys. \& Emot. Harm $\S 2$ (2010) provides:

A person acts recklessly in engaging in conduct if:

(a) the person knows of the risk of harm created by the conduct or knows facts that make the risk obvious to another in the person's situation, and 
Some of the earlier rabbinic sources favor doctors even more than does the Shulhan Arukh. A statement in the Babylonian Talmud ${ }^{46}$ suggests total immunity for doctors who try to heal a patient. The Meiri ${ }^{47}$ and a commentary erroneously attributed to the Ran adopt this view. ${ }^{48}$ According to the Tashbetz, Rabbi Simeon ben Tzemach Duran, physicians are not liable for unintended injuries even if they did more than was appropriate as long as they intended to heal. ${ }^{49}$ The Tashbetz imposed greater liability on surgeons. If a surgeon did more than was appropriate he was liable for an intentional tort for non-fatal injuries and for murder in case of death. ${ }^{50}$ If the surgeon did what was appropriate, then he was liable in a court of heaven for injuries caused by his recklessness (she-shagag be-peshi'uto) and would be exiled in case of death. Nonetheless the Tashbetz said that empirics - those "who rely on their own experiments" - and physicians who speak in the presence of a greater physician face punishment in gehenom whereas those who behave properly will have their heavenly reward. ${ }^{51}$

The rabbis treated medical injuries differently from other tort cases and from other cases involving craftsmen. In tort cases, Jewish law imposes liability for nezek if the defendant's body causes injury even where the defendant acted under compulsion ( $o$ 'ness).$^{52}$ Jewish law holds paid craftsmen liable for damaging the item that they are paid to work on. ${ }^{53}$ The Tosefta says that the rule for doctors was based on a need for "the better ordering of society." ${ }^{54}$ The Tashbetz said that this was necessary to en-

(b) the precaution that would eliminate or reduce the risk involves burdens that are so slight relative to the magnitude of the risk as to render the person's failure to adopt the precaution a demonstration of the person's indifference to the risk.

46. B. Sanhedrin $84 \mathrm{~b}$.

47. Rabbi Menachem Meiri (1249-c. 1310), commentary on B. Sanhedrin 84b.

48. Ran, commentary on B. Sanhedrin $84 \mathrm{~b}$.

49. Rabbi Simeon ben Tzemach Duran (1361-1444), Responsa Tashbetz 3:82.

50. See also Rabbi Yehezkel Abramsky (1886-1976), Hazon Yehezkel, Tosefta Gitin 3:13.

51. Id. Empirics rejected all theory and taught that medical treatment could be guided only by experience. See CuMSTON, supra note 3 at 115-16; Roswell PARK, AN EPITOME OF THE HistoRy OF MEdicINE 14 (1897). See generally, Friedell, supra note 18, at 13.

52. The Tosafot introduced the concept of exempting a person if he acted under an absolute compulsion (o'ness gamur). Tosafot BK $27 \mathrm{~b}$ s.v. U'shmuel. If injury is caused by a person's property (nizkei mammon), liability is limited to depreciation. Shulhan Arukh, Hoshen Mishpat 405:1.

53. Shulhan Arukh, Hoshen Mishpat 306:1, 4. See also Maimonides, Hil. Sekhirut 10:5. Although paid bailees are exempt if damage occurs in certain ways, the standard of care is higher than a negligence standard. For example, paid bailees are liable if the goods are stolen in secret but are exempt in case goods are taken by an armed bandit. Some hold that they are liable for goods stolen in secret regardless of the precau-

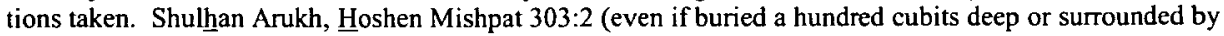
an iron wall). Others hold that paid bailees are liable only if they fail to exercise a high degree of care. Solomon Luria (1510-1573), Yam Shel Shlomo, Bava Kamma 6:11. The standard of care can also be set by agreement or by custom. Arukh Ha-Shulhan, Hoshen Mishpat 303:7.

54. Tosefta Gitt. 3:8 ("mipnei tikkun ha-olam"). 
courage physicians to practice medicine..$^{55}$

Given this background, it is striking that recent Israeli cases present a different picture of Jewish law. In Marciano $v$. Singer, ${ }^{56}$ Justice Rubinstein quoted from an article by Rabbi Shlomo Dichovski who summarized the rabbinic sources and concluded, "if a doctor did his job negligently, did not perform appropriate tests or neglected the patient, he is liable in a human court." $" 57$ Justice Rubinstein qualified this by saying that the matter is not simple and that a tension exists between the laws of heaven and those of a human court given the need not to discourage doctors from practicing medicine. ${ }^{58}$ This is an extraordinary statement as Jewish law does not recognize the concept of negligence. ${ }^{59}$ Rabbi Dichovski went further, saying, "It is hard to assume" that the doctor's liability under the laws of heaven refers to professional malpractice. ${ }^{60}$ Instead Rabbi Dichovski argued that doctors are liable in a heavenly court only if they failed to make a fundamental analysis in a routine case, but if they are negligent, they are liable by analogy to a paid expert slaughterer who is liable in such cases. ${ }^{61}$

Rabbi Dichovski's argument is not compelling. In Jewish law the paid expert slaughterer, whose liability is based on his status as a bailee ${ }^{62}$ is liable for the loss of value if his slaughtering makes the animal no longer kosher ${ }^{63}$ The basis of liability is strict, not negligence, and is dependent on his being paid. ${ }^{64}$

As we saw, Justice Rubinstein in Marciano said that Jewish law imposed liability for a doctor's negligence. It did not take long for others to import the concept of reasonable care into Jewish law as well. This happened in D.M. v. Red Crescent Hospital ${ }^{65}$ where Judge Shapira surveyed relevant Jewish law based on an article by Rabbi Yosi Sharabi. ${ }^{66}$ Quoting

\footnotetext{
55. See Rabbi Simeon ben Tzemach Duran, supra note 49.

56. CA 9656/03 [2005] IsrSC Tak-El 2005(4) 125.

57. Id. at |24(2), quoting Shlomo Dichovski, "Miteshuvotav shel rav l'rofe," 17 TECHUMIN 327, 332 (1996/97).

58. 1 d.

59. See supra note 40; Steven F. Friedell, The Role of Jewish Law in a Secular State, JEWISH LAW ASSOCIATION STUDIES (forthcoming).

60. Shlomo Dichovski, "Miteshuvotav shel rav l'rofe," 17 Techumin 327, 332 (1996/97). See also Michael Wygoda, Ve-rapo Yerape, Achrayut ha-Rofe be-Nezikin, Parashat ha-Shavu'a no. 415 (2013), available at http://www.justice.gov.il/MOJHeb/MishpatIvri/Parashot/gilyonot.htm (last visited February 18, 2013) (Jewish law imposes liability on doctors for negligent errors).

61. Id.

62. See supra note 53.

63. Shulhan Arukh, Hoshen Mishpat 306:4. He is not liable if the animal was rendered tereifa as a matter of doubt. Id. at 306:5.

64. The expert slaughterer is exempt if he acts gratuitously. Id. at 306:4.

65. CC (Jer) 7513/05 (2008) IsrDC Tak-Mah 2008(2) 3402.

66. Yosi Sharabi, Ahrayut Beit $\underline{\text { Holim }}$ begin Ikuv be-matan tipul refu'i, available at
} 
from that article, he wrote:

Based on the foregoing, if a doctor did all that is required to diagnose the disease, acted in a reasonable manner, provided medical care according to the accepted practice, and did not consult with a more expert doctor either because he was unable to do so or where this was unnecessary in the circumstances, then he is exempt if he injured the patient through an error in judgment. In such cases it is said, "the doctor's error was God's will." ${ }^{.67}$

Other late 20th-century rabbis also wrote that negligent doctors would be liable in a human court, at least in some circumstances. For example, Rabbi Hayyim David Halevi, the late Sefardi Chief Rabbi of Tel Aviv-Yafo, held that if a doctor erred either in making a diagnosis or in designing a course of treatment, he would be liable under the laws of man if no doctor having the appropriate intelligence would make the same mistake ${ }^{68}$ However, a doctor would be liable only under the laws of heaven if a doctor made the correct diagnosis and established the correct treatment but the doctor's careless act or omission caused damage. ${ }^{69}$ The only earlier source that supports this distinction is the Tashbetz's responsum that differentiated between the surgeon who did what was appropriate and the one who did more than appropriate. ${ }^{70}$ The Tashbetz said that a surgeon who acted appropriately but injured a patient through his inadvertence or fault would only be liable in a heavenly court, suggesting perhaps that a surgeon who correctly designed the surgery might have erred in the execution. However, the Tashbetz made this rule only for surgeons, not for physicians, and the Shulhan Arukh did not codify his ruling.

Rabbi Yitzchak Silberstein, a leading haredi rabbi in Israel, wrote that a dentist would be exempt if he made a common mistake in judgment

http://www.netanya.ac.il/ResearchCen/JewishLaw/AcademicPub/Torts/Documents/opinion_23032008-

1.pdf (last visited September 27, 2012).

67. D.M. supra note 65 , at 20 (emphasis added). Rabbi Halevi also used the term "reasonable" in describing the doctor's duty of care, but he appears to have meant something different than the common law understanding. See Aseh Lekha Rav, supra note 27. He wrote that a mistake is reasonable "if any doctor would make the same mistake," implying a stricter standard than the common law, but then wrote "if a doctor made a mistake that no other doctor having the appropriate level of intelligence would make, then there is a basis for holding him liable," implying a standard closer to gross negligence. Id. By contrast, the common law requires doctors "to exercise the skill, knowledge, and care normally possessed and exercised by other members of their profession" or to "exercise such reasonable care, diligence, and skill as reasonably competent physicians" would exercise. DAN B. DOBBS, THE LAW OF TORTS 632 (n.7 and accompanying text) (2000).

68. Aseh Lekha Rav, supra note 27, at 138, 143.

69. Id. at 142.

70. See supra note 49. 
but that he would be liable if he was negligent and did not learn sufficiently or did not properly investigate. ${ }^{71}$ Rabbi Silberstein relied on two sources, neither of which provides strong support. The first, Misgeret HaShulhan published in 1840 by Rabbi Castelnuovo, said, "If it is clear based on the doctor's testimony that he erred regarding a basic precept ("devar mishnah") due to lack of study that even the physician would be liable."72 Rabbi Castelnuovo was commenting on the Tashbetz's distinction between the complete exemption for physicians and the greater liability for surgeons for unintentional injuries. It is not clear if Rabbi Castelnuovo meant to impose liability in the courts of man for a physician who made such a basic mistake, or only if he would be liable in a court of heaven. Even if the Misgeret Ha-Shulhan supported the greater liability, this was only according to the Tashbetz, a view that the Shulhan Arukh did not adopt. Moreover, the fault described by Rabbi Castelnuovo is not negligence - it is more serious, for it relates only to one who erred regarding a basis precept. This is consistent with Rabbi Castelnuovo's view that in case of shogeg karov le-mezid a doctor would be liable,$^{73}$ and as we have shown, ${ }^{74}$ this cannot fairly be described as a simple act of negligence.

Rabbi Silberstein's second source was the Hida's comment in Tov 'Ayin concerning the exile of a doctor that inadvertently kills a patient even though a parent or teacher would be exempt under similar circumstances. After noting the Tashbetz's distinction between surgeons and physicians, the Hida wrote:

According to all points of view, if a doctor knew that he did not recognize the disease and did not investigate but gave potentially fatal drugs and transgressed in that he was able to investigate and pay close attention, then it is possible that all of the rabbis would agree [that the doctor would not be exempt.] $]^{75}$

Some have read the Hida to mean that a doctor that erred out of laziness and lack of attention is liable in a court of man like any tortfeasor. ${ }^{76}$

71. Yitzchak Silberstein, Refu'at Shina'im - Hashpa'at Shikulim lo Refui'im, 11 ASSIA 46, 51(1987/88). The question presented was whether a dentist might tell a patient that another dentist had unnecessarily extracted a tooth where the tooth could have been saved by treatment. Rabbi Silberstein replied that if it was clear that the patient would sue the other dentist and that the other dentist would be liable for his negligence, then he ought to inform the patient.

72. Misgeret Ha-Shulhan supra note 38.

73. See supra text accompanying note 38 .

74. See supra notes $38-45$ and accompanying text.

75. Rabbi Hayyim Joseph David Azulai (Hida), Tov Ayin 9:8 (1786).

76. 7 AVRAham SteINBERG, ENTSIKLOPEDIA HILKHATIT REFU'IT 283 (2nd ed. 2006). See also R. Eliezer Waldenberg, Tzitz Eliezer, 5 Ramat Rahel 23 (who quotes Tov Ayin but omits the words "it is possible"). For a similar transformation, consider 1 Rabbi Nissim Avraham Ashkenazi, Ma'aseh Avraham no. 55 (Iz- 
The Hida may have instead meant that this physician, like a surgeon, would have to be exiled if he killed a patient. The problem troubling the Hida was why a doctor would be subject to exile even though a teacher or father who killed a child while beating him for purposes of instruction would be exempt. ${ }^{77}$ In an earlier work, Birkei Yosef, the Hida answered that the father and teacher were performing a mitzvah and acted as other fathers or teachers would. Whereas the doctor erred, even though his intention was to treat, and he ought to have paid closer attention. ${ }^{78}$ In his later work, Tov Ayin, the Hida said that in the described circumstances, even those who distinguish between physicians and surgeons, and even those who question the distinction between doctors and teachers, would exile the physician.

Moreover, the Hida's discussion is not a simple case of negligence. It is a much worse case - the doctor knew that he did not understand the disease, and yet prescribed potentially fatal medicines.

Recent rabbinic writings have also enlarged the types of damages that are recoverable in medical cases. Rabbinic law limits damages rather severely. Neither pain and suffering nor medical expenses are recoverable unless the plaintiff can demonstrate that the defendant acted with inadvertence close to intention (shogeg karov le'mezid). ${ }^{79}$ In recent years, some rabbis have stretched to find that a doctor's or dentist's negligence amounted to an intentional tort for which the defendant would be liable in a rabbinic court. ${ }^{80}$ This is obviously hard to maintain. Jewish law makes a fundamental distinction between intentional and unintended injuries. ${ }^{81}$

mir: 1855). There, Rabbi Ashkenazi wrote that a doctor who ignored contrary medical advice that warned of danger of the proposed treatment and caused injury or death as a result would be liable in a court of Heaven for injury and would be subject to exile for fatalities. Several people have read this source as imposing liability without qualification. Steinberg, id.; Yaron Ungar \& Yuval Sinai, Ripui Chayot veRashlanut Refu'it shel Vetrinar, at

http://www.netanya.ac.il/ResearchCen/JewishLaw/AcademicPub/Torts/Pages/Animals.aspx n.31 and accompanying text (last visited September 27, 2012). See also CC (TA) 33291-11-09 N.H.'A.B. v. Clalit Health Services [2011] IsrMC Tak-Shal 2011(4) 43866 (Klein, J.). Another source relied upon by the above authorities is R. Avraham Ashkenazi, Responsa Beit Aharon part 1, Yoreh De'ah siman bet:3." This appears to be in error. The likely intended source, Aharon Krispin, Sefer Beit Aharon part 1, Yoreh De'ah siman reish:3 (Izmir: Moda'i \& Ashkenazi, 1863), comments on parts of the Ma'aseh Avraham responsum, but it does not support a finding of liability in the courts of man for mistakes made by a licensed physician.

77. See M. Makk. 2:2; Maimonides, Hilkhot Rotzeah U-She'mirat Nefesh 5:6.

78. Birkei Yosef Yoreh De'ah 336:6. In Tov 'Ayin he mentioned a similar reading in Responsa Besamim Rosh 386 . There the author said that since the doctor's only mitzvah was to heal he is liable since he failed to heal the patient.

79. See supra notes 43-45.

80. 4 Rabbi Shmuel Halevi Wosner, Responsa Shevet Halevi no. 151 (1981) (dentist drilled on wrong tooth). See also 5 Rabbi Eliezer Judah Waldenberg, Tzitz Eliezer (Ramat Rahel) no. 23 (responsum undated, volume first published in 1956/57) (doctor injected wrong medicine).

81. E.g., B. Bava Kamma 27a. 
Although there is a teaching that rabbinic scholars must be careful because their inadvertent errors will be counted as if they were deliberate, ${ }^{82}$ rabbinic authorities prior to the twentieth century did not apply this dictum to physicians.

More recent writings produce a substantial change in Jewish law. In the past, Jewish law provided that a doctor that erroneously injured a patient was liable only in a heavenly court to pay the value of depreciation (nezek), and if the error resulted in death, then he was subject to exile. ${ }^{83}$ This was true even if the doctor failed to do all that was within his power. ${ }^{84}$ Under the new approach, Jewish law will impose liability in a human court for damages, including pain and suffering and medical expenses, for errors resulting from the lack of reasonable care.

There have been other efforts to achieve substantial reform of the Jewish law governing medical malpractice. Rabbi Yehiel Weinberg argued that a prerequisite for immunity in a court of man is that the doctor has "permission from the court," and since rabbinic courts today are not able to provide this permission, doctors are liable under the usual rubrics of tort law. ${ }^{85}$ Rabbi Weinberg's interpretation would hold doctors strictly liable for direct injuries. ${ }^{86}$ Rabbi Weinberg based his view on the Bet Hillel, a 17th-century commentator on the Shulhan Arukh. However, the Bet Hillel clarifies that permission of the kahal (the governing body of the local Jewish community) satisfies the requirement; ${ }^{87}$ in Israel, one could view the permission of the government as satisfying that requirement.

Others have suggested that the Shulhan Arukh's qualified immunity only applies to doctors who provide gratuitous care, and not to paid doc-

82. Pirkei Avot 4:13. See also B.M. 33b; Responsa Tashbetz 2:9 (a judge who errs a lot due to lack of care can be disqualified from judging); Rabbi Moses Alshech (sixteenth-century Turkey) commentary on Isaiah 1:17 (an immature judge can harm the world); Rabbi Solomon Luria (1510-1573), Yam Shel Shlomo Gitt. 1:36 (in some circumstances a judge is liable for his erroneous speech because his inadvertent errors are counted as deliberate).

83. See supra notes $16,20$.

84. Tov Ayin 9:8, supra note 75 .

85. 1 Kitvei Hagaon Rabi Yehiel Ya'akov Weinberg $z^{\prime \prime} t z l$ no. 45 at 82 (1997/98). See also 1 Ma'aseh Avraham no. 55, supra note 76 (beit din must be knowledgeable in medical matters if it is to be able to authorize a doctor to practice medicine). By contrast, most modem authorities assume that a doctor licensed by the government satisfies the requirement of having "permission of the court." E.g., Arukh Ha-Shulhan Yoreh De'ah 336; Aseh Lekha Rav supra note 69 at $138 \mathrm{n}$.; Dichovski supra note 57 at 331 . Rabbi Weitmeir contended that the doctor satisfies the requirement merely by having the patient's agreement to being treated by him. 1 Rabbi Meir Tzvi Weitmeir, Responsa Remetz Hashtmatot 11.

86. Kitvei Hagaon Rabi Yehiel Ya'akov Weinberg z"tzl, supra note 85, at 83.

87. Hillel ben Naphtali Zevi (1615-1690), Bet Hillel, Shulhan Arukh, Hoshen Mishpat 336:1. It was common for a kahal to hire a doctor to provide for the needs of all its members. JOSHUA LEIBOWITZ, TOWN PhysiCIans IN JewiSh SOCIAL HISTORY, in Intemational Symposium On Society, Medicine And Law 117, 121-122 (H. Karplus, ed. 1973). 
tors leaving them open to liability. ${ }^{88}$ If paid doctors were regarded as paid bailees, their exposure would be greatly increased since some require paid bailees to exercise at least a high degree of care. ${ }^{89}$

Others would expand liability by saying that the Shulhan Arukh limits liability to a court of heaven only for doctors who would otherwise face bankruptcy. ${ }^{90}$ Doctors not facing bankruptcy would be liable under the laws of man.

\section{OMISSIONS}

D.M. v. Red Crescent Hospital ${ }^{11}$ imposed liability for a hospital's failure to treat a woman in labor with twins. After waiting at the hospital for about thirty-five minutes, a nurse or midwife sent the woman to another hospital, where one baby was stillborn and the other suffered cerebral palsy and severe mental retardation. ${ }^{92}$ The court considered the Halakhic sources, and relying on an article by Rabbi Yosi Sharabi ${ }^{93}$ wrote:

This case deals principally with failure to treat by omission, and it is a general rule based on principles of Jewish tort law that an omission is not a basis for liability. Nonetheless there are exceptions, namely, when there is a pre-existing obligation between the plaintiff and defendant or where the plaintiff somehow relied on the tortfeasor, in which case he is liable under the laws of indirect damage (dina d'garmei). Babylonian Talmud Bava Kamma 99b-100a; Itamar Warhaftig, Undertaking in Jewish Law (Heb.)(Jerusalem: Jewish Legal Heritage Society, 2001), 419-45. Contemporary poskim have differed on this issue also. Rabbi Auerbach thinks that a doctor on duty in a hospital who negligently did not see a patient at night who asked him to treat him would be liable in tort. Also, Rabbi Elyashiv thinks that a patient who came to a certain doctor who negligently failed to treat him would be able to claim from him based on the reliance principle mentioned above. (Their opinions were quoted in Nishmat Avraham part 5, Yoreh Deah, § 336 (Jerusalem 5757), page 92.) However, Rabbi Waldenberg disagrees and

\footnotetext{
88. See Ungar \& Sinai, supra note 76 , at $\mathbf{n} .39$ and accompanying text. Others would exempt an unpaid doctor entirely if he was not grossly negligent. See Yaron Ungar \& Yuval Sinai at http://www.netanya.ac.il/ResearchCen/JewishLaw/AcademicPub/Torts/Pages/FreeClinic.aspx (at conclusion no. 4).

89. See supra note 53.

90. Tzvi Shechter, Tashlumei Rofe she-kilkel, Sha'arei Tzedek 1 (1999/2000) 49, 53-54.

91. Supra note 65.

92. Id. at iff 3,31 .

93. Sharabi, supra note 66.
} 
thinks that it is not possible to impose liability for damage caused by omission, such as failure to rescue another. (Responsa Tzitz Eliezer, vol. $19 \S 63$. His opinion was quoted in Nishmat Avraham, id. at 91-92.) ${ }^{94}$

What are we to make of this? According to the court, even in the absence of a pre-existing obligation, a doctor can become obligated to treat the patient if the patient relied upon the doctor. The court does not require reliance upon a promise or reliance induced by prior conduct. Apparently, the patient's belief that the doctor would treat her would suffice if this belief caused to her to take some action, such as waiting for thirty-five minutes. However, the court relied on a Talmudic source that is inapposite. The referenced portion of tractate Bava Kamma deals with a moneychanger who is liable for giving bad advice where it is clear that the owner of coin relies on his advice. ${ }^{95}$ This is not a case of omission - the moneychanger gave advice. The court's reliance on the other sources is also misplaced. Professor Warhaftig is careful to limit the discussion to situations where the defendant promised some action to the defendant. ${ }^{96}$ Rabbi Auerbach's opinion deals with a patient already admitted to the hospital, where there was at least an implicit promise of care, not like D.M. where the hospital did not admit the mother. This leaves us with Rabbi Elyashiv's opinion that relied entirely upon the moneychanger case. ${ }^{97}$

Although the line between omission and misfeasance is not always easy to draw, ${ }^{98}$ extending liability to cases of omission would mark a major change in Jewish law. The classical rabbinic sources exempt all tort defendants from liability in a human court for damages caused by omission. ${ }^{99}$

94. In another opinion based on Nishmat Avraham two scholars wrote, "[C]ontemporary poskim have emphasized that one should not distinguish between damage caused by a misfeasance and damage caused by omission. Therefore, a doctor who failed to provide proper treatment when he should have provided it is subject to tort liability if the patient thereby suffered damage." See Ungar \& Sinai supra note 87, text at n.33.

95. B. Bava Kamma 99b-100a.

96. ITAMAR WARHAFTIG, UNDERTAKING IN JEWISH LAW 420 n.71 (2001) (Heb).

97. Id. Rabbi Halevi said that a doctor who erred by either act or omission in treatment would be liable, but he provided no support for this assertion. Aseh Lekha Rav, supra note 27, at 142.

98. See e.g., Satterfield v. Breeding Insulation Co., 266 S.W.3d 347 (Tenn. 2008), where the court determined that a defendant's negligent act need not be an affirmative act but can be an entire course of conduct. Alcoa failed to tell its workers of risk of asbestos and worker wore his work clothes home. A daughter at home alleged that she contracted mesothelioma from being exposed to asbestos fibers on her father's work clothes. The court determined that the daughter's case should proceed to trial. $C f$. Nat'l Fed'n of Indep. Bus. v. Sebelius, 132 S. Ct. 2566 (2012) (Roberts, J.) (Congress has power under the Commerce Clause to regulate activity but not inactivity).

99. The attitude is reflected in the epigram quoted by Rabbi Silberstein mi she'eino oseh eino to 'eh ("One who does not act does not err."). Yitzchak Silberstein, Rofe she 'ta'ah ve-nahag ambulans she-daras, in 2 M. Hershler (ed). Halakhah U-Refu'ah, Machon Regensberg 287 (1981). 
In upholding this position, Rabbi Waldenberg principally relied on Nahmanides who likened a person's failure to rescue to that of a person's failure to testify. ${ }^{100}$ Even though it is a grave sin not to save another when one is able, there is no financial obligation for failure to do so. ${ }^{101}$ As applied to doctors, Rashi commented that a doctor who fails to treat a patient is destined for gehinom (Hell), but he makes no mention of tort liability. ${ }^{102}$ Moreover, the Tosefta imposes liability on a doctor who treats too much, but there is no mention of a liability for a doctor who treats too little. Rabbi Wozner offered a similar view, saying that the moneychanger case had no application to a doctor's failure to make a diagnosis. He wrote that a doctor is liable only for acts that directly cause injury "but not where he did nothing but erred and did not discover the disease."103

\section{INFORMED CONSENT AND BREACH OF AUTONOMY}

The modern law of informed consent is based on the idea of patient autonomy. In common law countries, it is malpractice to perform a medical procedure without obtaining the patient's informed consent, even if the doctor performs the procedure with reasonable care. ${ }^{104}$ Most states in the United States require the patient to show that she would have refused the treatment had she been informed of the risks and that her preferred choice was reasonable. ${ }^{105}$ The State of Israel goes further and imposes liability for breach of a patient's autonomy even if the patient would have consented to the medical procedure had she been properly informed. ${ }^{106}$ A court measures damages for loss of autonomy separately from the physical damage caused by failure to obtain informed consent. ${ }^{107}$

Jewish law takes a different approach. It begins with the idea that a person does not own his body, ${ }^{108}$ that each individual is obligated to take care of his health so that he can serve God, ${ }^{109}$ and that doctors have an ob-

100. Accord, File No. 5637, PDR 5:132, 139-40 (1962); File No. 257-53, 2 Piskei Din Yerushalayim Dinei Mammonot u-beirurei Yahadut 75, 79 (1994/95).

101. There is also no criminal penalty. Maimonides, Hilkhot Rotzeah u-Shemirat Nefesh 1:16.

102. Rashi, Kidd. 82a s.v. Tov.

103. Rabbi Shmuel Wosner, Responsa Shevet Ha-Levi 10:294.

104. See Nili Karako-Eyal, Has Non-U.S. Case Law Recognized a Legally Protected Autonomy Right?, 10 MNN. J. L. SCI. \& TECH. 671 (2009).

105. DAN B. DOBBS, THE LAW OF TORTS 657 (2000).

106. CA 2781/93 Daaka v. Carmel Hospital, IsrSC [1999] 53(4) 526.

107. Id. No damages for loss of autonomy are awarded when the operation is successful. CA 1303/09 Kadosh v. Bikur Holim Hospital, IsrSC [2012] Tak-El 2012(1) 4625 ๆ12 (Amit, J.).

108. Radbaz, commentary to Maimonides Hil. Sanhedrin 18:6.

109. Maimonides, Hil. De'ot 3:3. See also Resp. Radbaz 4:67; Magen Avraham Orah Hayyim 328:6. 
ligation to heal. ${ }^{110}$ None of the classical rabbinic sources impose tort liability for providing treatment without consent, let alone without informed consent. Yet in modern times, rabbis recognized that a doctor ought not treat a patient against his will where there is a high risk of failure, where the therapy is uncertain, or where the treatment against the patient's will would be traumatic." Because it rarely happens that treatment without a patient's consent will be risk-free, certainly effective, and non-traumatic, as a practical matter, Jewish law requires the doctor to obtain the patient's consent before treatment. ${ }^{112}$

The question remains, however, whether treatment without consent subjects the doctor to tort liability. In Chelmski v. State of Israel, ${ }^{113}$ Judge Drori recounted the Jewish law in this area. Quoting Dr. Steinberg's Encyclopedia of Halakha and Medicine, he wrote, "If the treatment is beyond that which is usual, then even if the doctor's intention was proper, he is judged to be a tortfeasor (dino $k^{\prime}$ hovel) if he did not expressly obtain the patient's consent."114

If failure to obtain consent makes the doctor a tortfeasor under Jewish law, then the door is open to saying that lack of informed consent should do the same. Judge Drori took a step in that direction in a later case, Es-

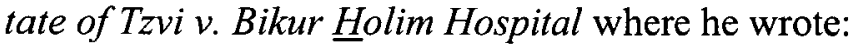

In addition to these sources one can find in Jewish law a number of rules on related topics, from which one can conclude that a patient has a right to autonomy. The examples relate to the choice of the doctor, yet in my opinion it is all the more appropriate to apply it to the patient's right to autonomy in the choice of the medical treatment that will be performed on his body. Providing full information by the therapists is a pre-condition for the exercise of the patient's right of independent choice. Therefore, the medical staff's failure to provide the plaintiff full explanations constitutes a breach of her autonomy, even according to Jewish law. ${ }^{115}$

Justice Rubinstein has recently endorsed the view that the concept of informed consent has taken root in Jewish law, although, perhaps in a

110. See Shulhan Arukh, Yoreh Deah 336:1, supra note 16.

111. Daniel Sinclair, The Obligation to Heal and Patient Autonomy in Jewish Law, 13 J. OF L. \& RELIGION 351,370 (1999).

112. Id.

113. CC (Jer) 3161/01 (2005), IsrDC 2005(1) Tak-Mah 5809.

114. Id. at 970 quoting 2 AVRAHAM STEINBERG, ENTSIKLOPEDYAH HILKHATIT REFU'IT 31 (1988).

115. CC (Jer) 3235/01 Estate of Tzvi v. Bikur Holim Hospital [2007] IsrDC Tak-Mah 2007(2) 9738 at q209 (Drori, J.) 
more limited form than in Israeli law. ${ }^{116}$

However, the matter is more complicated. Dr. Steinberg's encyclopedia, which was the basis for this innovation, cites a comment by an anonymous rabbi for support. That rabbi who said the doctor would be a "tortfeasor" for providing treatment without a patient's consent also wrote, "The doctor is not required to explain the nature of the treatment, its risks, and consequences." 117 That is, Jewish law requires the patient's consent, but not her informed consent. Further, this rabbi placed quotation marks around the word "tortfeasor" suggesting that although wrongful, no tort liability would result from failure to obtain consent. ${ }^{118}$

In another development, Justice Hendel has maintained that Jewish law supports the Israeli law of imposing tort liability for breach of autonomy even where the patient would have still opted to undergo the same procedure had she been informed of the risks. In addition to other sources, Justice Hendel recounted the halakhic rule that if a person's animal or tree must be killed or cut down because it poses a risk to the public, and a third party kills the animal or cuts down the tree without the owner's consent, the owner is entitled to compensation. The explanation is that the third party that kills the animal or cuts down the tree deprives the owner of the opportunity to perform a mitzvah. ${ }^{119}$ Even though the third party in a sense did the owner and the world a favor, he nonetheless deprived the owner "of the right to act as he might choose with regard to his property." 120 One could distinguish the situations - depriving an owner of the chance to perform a mitzvah with regard to his property is not the same as depriving a patient of making an informed choice, especially since the doctor is obligated to heal.

\section{JEWISH LAW AND THE MODERN WORLD}

The Shulhan Arukh and earlier texts impose different rules of liability for medical injuries from those found in modern Western legal systems. This should come as no surprise since rabbinic law has different goals from modern legal systems. In Jewish law, compensation for personal injury is not an end in itself but a means to achieving atonement. ${ }^{121}$ The goal

116. Kadosh, supra note 107 at 4697 (Rubinstein, J.).

117. Avraham Steinberg, supra note 114.

118. Avraham Steinberg, Editor's notes, 3 SEFER ASSIA 324 (1983/84).

119. CA 9936/07 Ben David v. Entabi [2011] IsrSC Tak-El 2011(1) 2443 ๆ12 (Hendel), quoting Maimonides Hilkhot Hovel U-Mazik 7:13. Justice Rubinstein also found a right of autonomy supported by Jewish law. CA $8126 / 07$ Estate of Tzvi v. Bikur Holim Hospital [2010] IsrSC Tak-El 2010(1) 300 at $\uparrow 15$.

120. Ben David, supra note 119 , at $\$ 12$.

121. See M. Sanh. 4:5; B.K. 103b; Code of Maimonides, Hilkhot Hovel U-Mazik 5:9; Shulhan Arukh, Ho- 
of atonement can at times trump a victim's right to compensation. ${ }^{122}$ At other times, it can require a remedy even where the actor causes an accident without fault. ${ }^{123}$ Concepts of negligence and reasonable care that excuse conduct that is cost effective ${ }^{124}$ are not found with Jewish law. In tort cases, the rabbis generally measured damages in a manner that they knew favored the defendant. ${ }^{125}$ As we have seen, from the Middle Ages through at least the sixteenth century, rabbis went further in limiting a doctor's liability out of a perceived need for the betterment of society.

However, today the classical rabbinic law of medical liability does not fit society's felt needs and expectations. Society expects that doctors will be liable for injuries resulting from substandard medical care, whether caused by acts or omissions, even if the doctor did not intentionally injure the patient. There is a similar expectation of patient autonomy.

This presents a quandary both for those in the haredi communities, for whom halakha governs their daily lives, and for those in the Mishpat Ivri movement, who want Jewish law to play a role in shaping Israeli law. The importance of Jewish law differs for these two groups. For those within a haredi community, if halakha fails in a major way to satisfy one's important needs and expectations, it may weaken one's adherence to the entire system. For the Mishpat Ivri movement, the problem is different. Failing to modernize the limited liability of doctors as codified in the Shulhan Arukh would not seriously threaten Israeli law. However, respect for Jewish law as a source of authority would be threatened. For this group, the problem has intensified since the Foundations of Law Act of $1980^{126}$ that made Jewish law the source of Israeli law when there is a gap in the law, ${ }^{127}$ and since Israel adopted a Basic Law establishing "the values of the State of Israel as a Jewish and democratic state." 128 Since both groups need to modernize the Jewish Law, the question is how to best accomplish it.

For Israeli Jews, one might think that the simplest way of resolving

shen Mishpat 422:1; R. Moshe Sternbuch, Teshuvot Ve-Hanhagot 1:868 (1991/92); Rabbi Zalman N. Goldberg, "Rashlanut Refu'it," 19 Techumin 317 (1998/99).

122. See Code of Maimonides, Hilkhot Gezelah Ve-Aveidah 1:13.

123. E.g., Responsa Maharam Lublin 43 and 44.

124. United States v. Carroll Towing Co., 159 F.2d 169 (2d Cir. 1947).

125. E.g., B.K. $47 \mathrm{a}$

126. 34 LSI 191 (Isr.).

127. For a discussion of some of interpretations of the 1980 Act, see Some Observations about Jewish Law in Israel's Supreme Court, supra note 31, at 660 n.5.

128. Basic Law: Human Dignity and Liberty, 1992 S.H. 1391, available at THE KNESSET, http://www.knesset.gov.il/laws/speciaL/eng/basic3_eng.htm. As former Justice Barak has observed, the provisions of this Basic Law apply "in interpreting all of the provisions of the Israeli constitution and statutes." The Values of the State of Israel as a Jewish and Democratic State, supra note 32 at 7. 
the tension would be to recognize the State of Israel as having the power of the kahal, which would give Israeli non-rabbinic courts the status of kahal courts with the power to apply a set of non-halakhic rules. In medieval times, rabbis faced a similar quandary of how to use Jewish law to govern. Because the rabbis recognized that Jewish law was often impractical, they allowed Jewish communities to adopt necessary regulations under rabbinic supervision. ${ }^{129}$ Nonetheless, in several instances, some rabbis found a basic policy in the Bible or in rabbinic literature that supported the departure from the halakhic rule. ${ }^{130}$ Use of halakha in this way avoids having to make a complete break with the Jewish tradition while pursuing a different result than would be reached if halakha were to govern the case. Although a few rabbinic courts have recognized a few pieces of Knesset legislation as having the status of takkanot ha-kahal, ${ }^{131}$ rabbinic courts have not yet applied that status to non-rabbinic court decisions. Moreover, both haredi and Mishpat Ivri groups would likely reject this model. For the haredi community, it would cede power to secular judges who operate without rabbinic supervision. For the Mishpat Ivri movement, it would undermine the movement's raison d'être, which is to use halakha to shape the secular law.

Another model would recognize the classic rabbinic rules as default rules subject to being set aside by agreement, and that the patients and doctors have implicitly agreed to apply Israeli medical malpractice law or that such law had become the custom within the community. ${ }^{132}$ A solution of this type, however, would also not be acceptable. It would frustrate those who seek to have halakha directly govern their daily life, and it would defeat the very purpose of the Mishpat Ivri movement, as halakha would not play a meaningful role in the development of Israeli law.

The method that the Israeli legal community has taken - radical reinterpretation of earlier texts - seems to be, despite its costs, the most practical means of reform. Within Jewish law, as within any legal system, there is often tension between the demands of precedent and the yearning for solutions that meet the felt needs of the time. Justice McClean of the United States Supreme Court faced this difficulty in trying to adjust the rules of admiralty jurisdiction derived from English sources to the needs of his time and place. He wrote:

129. See e.g., Rabbi Solomon ben Abraham Aderet (c. 1235-1310), Responsa Rashba 4:311.

130. E.g., Responsa Rabbi Nissim ben Reuven Gerondi (c. 1310-1375) 30 (using metaphor from Nehemiah 3:35).

131. Menachem Elon \& Yehiel Kaplan, Takkanot, 19 EnCYCLOPAEDIA JUdAICA 451 (2d ed. 2007).

132. See Ron S. Kleinman, Civil Law as Custom: Jewish Law and Secular Law - Do they Diverge or Converge?, 14 THE REVIEW OF RABBINIC JUDAISM 11 (2011). 
Antiquity has its charms, as it is rarely found in the common walks of professional life; but it may be doubted whether wisdom is not more frequently found in experience and the gradual progress of human affairs; and this is especially the case in all systems of jurisprudence which are matured by the progress of human knowledge. Whether it be common, chancery, or admiralty law, we should be more instructed by studying its present adaptations to human concerns, than to trace it back to its beginnings. Every one is more interested and delighted to look upon the majestic and flowing river, than by following its current upwards until it becomes lost in its mountain rivulets. ${ }^{133}$

Rabbi Uziel, who would later become the first Sephardic Chief Rabbi of Israel, expressed a similar attitude in the introduction to his responsa. He said that a judge who merely decides a case based on the written precedents fails in his task, and must instead purify and refine the law based on an enlarged understanding not only of changed circumstances, but also of changed values. ${ }^{134}$

One might contend that there is a vast difference between developing Jewish law to apply to new technologies and developing the law based on changed values. In the former situation, one must probe the reasons behind the rules and apply them as best as one can to the new circumstance. The latter situation involves a change in the rules themselves. However, the difference between the two situations may not be great. Even when the older rules are clearly stated, they may have been formulated to address a set of circumstances and beliefs and as those change, a new set of rules may be necessary to give effect to the broader purpose underlying the original rule. ${ }^{135}$

133. Jackson v. The Steamboat Magnolia, 61 U.S. (20 How.) 296, 307 (1857) (McLean, J., concurring). 134. 1 Rabbi Ben Zion Meir Chai Uziel, Sefer Mishpetei Uziel ix (1935). See also CA 9183/09 Football Ass'n Premier League Ltd. v. Anonymous [2012] IsrSC Tak-El 2012(2) Tak-El 2608 at ๆ 6 (Hendel, J.).

135. The development of admiralty jurisdiction in the United States provides a parallel. Technological developments, such as the invention of steamboats and airplanes, have of course required a reconsideration of the purposes of admiralty law. See The Genesee Chief v. Fitzhugh, 53 U.S. 443 (1851) (steamboats); Executive Jet Aviation, Inc. v. City of Cleveland, 409 U.S. 249 (1972) (airplanes). Of equal significance, changed political settings have also forced the courts to consider reformulating older rules. For example, in England the High Court of Admiralty's jurisdiction was restricted to cases arising within the ebb and flow of the tide and outside the body of a county. 13 Rich. II, c. 5; 15 Rich. II, c. 3. See The Thomas Jefferson, 23 U.S. 428 (1825). The United States Supreme Court changed the rule, not because it was difficult to apply but because the legal, political, and economic contexts were different. In England, the rule distinguished between the Admiralty's jurisdiction and that of the common law courts, all national courts of England; in the United States the rule set the boundary between federal and state courts. Reinterpreting the rule, the Court said that its underlying purpose was to allow admiralty jurisdiction over navigable waters. The Genesee Chief v. Fitzhugh, supra note 135. As reformulated, the rule allowed federal courts to further the federal interest in regulating maritime commerce, which was arguably one purpose of having federal admiralty jurisdiction. See Charles L. Black, Jr., Admiralty Jurisdiction: Suggestions and Critique, 50 
Modern inventions like the X-ray and other advanced techniques, have required rabbis to re-examine the distinction that some Jewish authorities made between external and internal maladies because now almost all conditions can be seen and examined. ${ }^{136}$ More fundamentally, one may argue that the classical Jewish sources limited liability because doctors and patients had lower expectations, and because medical providers were uninsured. Moreover, the classical sources addressed a fundamentally different type of medical practice - one based on a priori assumptions rather than science - than the medicine of today. The classical sources protected doctors from personal liability when medical care was largely a matter of uncertain outcomes. As reflected in the Shulhan Arukh, ${ }^{137}$ doctors had enough reason to fear injuring their patients that they might refrain from practicing medicine. Modern medicine is not perfect, and in some instances, doctors and patients share a belief in harmful or useless treatment based on non-scientific theory. ${ }^{138}$ However, doctors today are at least capable of following the scientific method and of having a better understanding of many risks. They can also insure against personal liability. Consequently, although Jewish law dating back to the Tosefta relaxed tort liability out of concern for the social order, today that concern counsels in favor of greater liability. ${ }^{139}$

That is not to say that doctors should be held strictly liable for the injuries they inflict. The Shulhan Arukh essentially embodies two takkanot (legislations). The first is that doctors will not be liable without regard to fault under the usual tort rule governing injuries directly inflicted by a person's actions - that of adam mu'ad le'olam ("a person is always fully liable") ${ }^{140}$ - nor will they be liable under the rules applicable to bailees, but will face liability only in case of error-in effect liability only for malpractice. The second takkanah is that a doctor's liability for error will be only in heavenly courts. The first takkanah is still necessary since much standard medical treatment entails some inherent injury and retains enough risk of causing unforeseen harm. However, the second takkanah is no longer necessary and should be seen as addressing a different type of activity distinct from modern medicine. My approach comes to the same result as that reached by Rabbi Dichovski. He thought that the Arukh HaShulhan's limitation of liability to a heavenly court was not addressing

COLUM. L. REV. 259, 261 (1950).

136. 4 Responsa Shevet Halevi no. 151 supra note 80.

137. See supra note 16 and accompanying text.

138. See supra note 2.

139. See Chelmski, supra note 113 , at 985 .

140. See Wygoda, supra note 60. 
professional malpractice. ${ }^{141}$ I think that it was not addressing modern scientific medicine.

If doctors are to be held liable for their errors in courts of man, the next issue is the scope of that liability - does it extend to pain and medical care, or only include depreciation? It would seem best to adopt the position of treating a doctor's inadvertence as if it were intentional. ${ }^{142}$ This would place doctors on the same level as judges ${ }^{143}$ to whom they are often compared, and it would ensure that injured patients be compensated for the full range of injuries that Jewish tort law allows. All of a doctor's errors meaning instances where the doctor deviated from accepted standards should be treated as instances of inadvertence that are treated as if they were intentional.

One may also address the issue of informed consent from within the framework of Jewish law. Classical rabbinic texts expressed skepticism as to whether a person could validly consent to any injury. Even if a person expressly said, "Break my arm on condition that you will not be liable," one could legitimately contend that he was speaking sarcastically. ${ }^{144} \mathrm{~A}$ similar skepticism can lead Jewish law to allow claims by patients who would not have consented to treatment had they been informed of the pertinent risks. Justice Hendel's use of Jewish law to support the right to autonomy under Israeli law is also proper. ${ }^{145}$ Although one can distinguish the situations, at least Jewish law recognizes the obligation to pay damages in some situations where a person loses a right to choose.

The final issue concerns omissions for which classical Jewish law does not impose liability. ${ }^{146}$ It would seem that the best way to handle this is to carefully scrutinize whether a case involves misfeasance or nonfeasance, and many instances of omissions can probably be classified as the former. ${ }^{147}$ For example, a physician who fails to order a certain test or perform a certain examination may still be guilty of misfeasance for then discharging the patient.

These types of radical reinterpretation have supporting precedents. The Tashbetz met the needs of its time by distinguishing between surgeons and physicians, interpreting the Tosefta as applying only to the former and distinguishing between trained physicians and the empirics who relied on

\footnotetext{
141. See supra note 60 and accompanying text.

142. See supra note 80 and accompanying text.

143. See supra note 82 and accompanying text.

144. E.g., Shulhan Arukh $\underline{H}$ oshen Mishpat 421:12.

145. See text at note 119.

146. See supra text at notes $99-102$.

147. See supra note 98 and accompanying text.
} 
no theory. ${ }^{148}$ When Ibn Ezra interpreted the Bible as prohibiting the treatment of internal conditions, his conclusions coincided with some of the medical theory of his day. ${ }^{149}$ Although these interpretations were not universally adopted, and both have largely been displaced, they did, for a period, reconcile earlier legal texts with then-current values. As values and circumstances continue to change, further adaption to the rules governing medical liability will be necessary. 
